\title{
Nematodes Associated with Kiwi Plants in Central Horticulture Centre Kirtipur, Kathmandu, Nepal
}

\author{
Bijay Chhetri, Janak Raj Subedi* \\ Central Department of Zoology, Institute of Science and Technology, Tribhuvan University, Kirtipur, Kathmandu, Nepal
}

\section{Email address:}

janzoology@gmail.com (J. R. Subedi)

${ }^{*}$ Corresponding author

\section{To cite this article:}

Bijaya Chhetri, Janak Raj Subedi. Nematodes Associated with Kiwi Plants in Central Horticulture Centre Kirtipur, Kathmandu, Nepal. International Journal of Applied Agricultural Sciences. Vol. 5, No. 3, 2019, pp. 71-74. doi: 10.11648/j.ijaas.20190503.12

Received: May 10, 2019; Accepted: June 10, 2019; Published: June 25, 2019

\begin{abstract}
Plants provide space for the occurrence of different trophic groups of nematodes. The occurrence of nematodes near the rhizosphere of plants, such as parasitic, free-living etc. can determine the survival of plants and finally the production of plants. Altogether 40 samples from the $30 \mathrm{~cm}$ apart from the kiwi plants were tested to identify the distribution of nematodes in Kiwi plants at Central Horticulture Centre, Kirtipur, Kathmandu, Nepal. All together 10 genera of nematodes including both free living/beneficial and parasitic were identified during the study period. Overall, 830 individuals of 10 nematodes were found to be associated with Kiwi plants, among them order Rhabditida was reported to be the highest (40.96\%) which was followed by Mononchida (33.74\%), Dorylaimida (15.66\%) and Tylenchida (9.64\%). These four genera of plant nematodes have been reported for the first time associated with Kiwi plants in Nepal. The result indicated that the nematodes are not significantly distributed in all Kiwi plants. For more production we recommend proper management of manures and Kiwi plants treatment.
\end{abstract}

Keywords: Kiwi, Nematode, Parasites, Soil, Plant

\section{Introduction}

Nematodes are probably origin in the Cambrian [1]. Terrestrial nematodes coexisted with plant probably since the origin of plants between 425 and 490 mya [2]. Based on ecological resources used, nematodes are partitioning into free-living and parasitic. Fee-living nematodes are cosmopolitan in distribution, however due to temporal and spatial changes in the habitat, some of the nematodes have evolved parasitic relationships with other eukaryotes [3, 4]. Soil nematodes are both beneficial and harmful to the plants. Harmful nematodes are more detrimental to the crop production and huge loss to the farmers [5]. For example, per year approximately 100-157 US\$ crop production is lost from the nematodes worldwide [6]. To minimize the crop loss from disease and parasites farmers are practicing crop rotation $[7,8]$. However, the practice won't be possible to perennial plants such as Kiwi.

Kiwi (Actinidia delicosa) plants provide space for living various trophic groups of nematodes, namely, algivorous
(Dorylaimus Spp., Discolaimus Spp., etc.), and different stages of insects and animal parasites like Mermis Spp., Sphaerularia Spp., Eudiplogaster larva and Deladinus female, etc. [9]. The generally occurring herbivore nematodes in plants are Tylenchida, Aphelenchida and Dorylaimida [10]. In addition, the free-living bacterivore nematodes, such as Rhabditis Spp., Mesorhabditis Spp., Eucephalobus Spp. and Cephalobus Spp., etc. are common in the plants, and beneficial to plants for providing nutrients through decomposing organic matters [11]. Similarly, fungivores nematodes, such as Aphelenchus Spp., also decomposes organic matters [10]. However, least abundant predatory nematodes in most of the soil contents such as Mononchus Spp. feed indiscriminately both plant parasitic and free-living nematodes [11].

Kiwi (Actinidia delicosa), belonging to the order Ericales and family Actinidiaceae normally ripens within 25 weeks after the flowers first appear [12]. The fruits of Kiwi are beneficial because of its contribution of vitamin A, B, C, E and $\mathrm{K}$, potassium, copper, folate, and fiber to the people ${ }^{[13]}$. Because of these nutrients available in Kiwi fruit, its demand 
is increasing mainly for cancer causing and heart disease patients, pregnant women and small children [13]. However, the production of Kiwi is decreasing, probably due to the effects of parasitic nematodes such as Meloidogyne Spp., Helicotylenchus Spp., Heterodera Spp., Pratylenchus Spp., Paratylenchus Spp., Tylenchus Spp. and Paratrichodorus Spp. [14]. Because of the nature of host-parasite relationship, we expect all Kiwi parasite are equally distributed in all Kiwi plants. In Nepal, till date no more research indicated the occurrences/distribution of soil nematodes on Kiwi plants. Therefore, the present study aims to minimize this research gap.

\section{Materials and Methods}

The present study was carried out on the Kiwi plants at Central Horticulture Centre (CHC), Kathmandu, Nepal. Geographically, it lies in between $27^{\circ} 40^{\prime} \mathrm{E}$ latitude and $85^{\circ}$ $17^{\prime} \mathrm{N}$ longitude, at $1320 \mathrm{~m}$ of elevation [15]. The study area covers 20 hectors of land, and the Kiwi plants were introduced in CHC in 1987/88 [16]. Fifty-six Kiwi plants are planted in $2542.5 \mathrm{~m}^{2}$ of CHC, Kathmandu.

We selected randomly 40 Kiwi plants to collect Kiwi plants related soil nematodes. We dug $20 \mathrm{~cm}$ soil from $30 \mathrm{~cm}$ apart from the Kiwi plants, and took 500 gm of soil. We kept the sample soil in plastic bags with proper tagging. The chunks were smashed, and pebbles were removed from soil samples by hand. The samples were then processed by Cobb's sieving and decantation techniques [17] (mesh size: $200 \mathrm{~mm}$ and $53 \mu \mathrm{m}$ ) with continuous wash with fresh water. The nematode suspension obtained from soil sample was transferred to Baermann's funnel [18] and left for 24 hours to allow the movement of nematodes to the bottom of the funnel. Total $10 \mathrm{ml}$ of nematode suspension was prepared and $1 \mathrm{ml}$ out of $10 \mathrm{ml}$ suspension was taken into a counting disc for nematodes counting and result was multiplied by 10 . The nematodes were then killed and fixed by Seinhorst's process [19] with the help of $4 \%$ formaldehyde heated at 60 $70^{\circ} \mathrm{C}$. Nematodes were dehydrated in a desiccator for 1 week [20] and slides of nematodes were prepared by using glycerin, purified wax and hot plat. The slides were observed under the low power and high-power magnification. i.e. 10× (eye piece) and $10 \times, 20 \times$ and $40 \times$ (nose piece) from left to right side of the slide. The nematodes were identified up to Genus by comparing the characters of observed nematodes with available taxonomic keys [21]. The distribution of Kiwi nematodes was analyzed in R Program [22].

\section{Results and Discussion}

Altogether 10 genera of Kiwi nematodes (Figure 1) belonging to 4 orders were observed from the 40 Kiwi plants in the Central Horticulture Centre during the study. Among the observed nematodes 750 were beneficial (Cephalobus Spp., Discolaimus Spp., Dorylaimus Spp., Eucephalobus Spp., Iotonchus Spp., Mesorhabditis Spp., Mononchus Spp., Parahadronchus Spp. and Rhabditis Spp.) and 80 were harmful (Helicotylenchus Spp.). The distribution of nematodes in Kiwi plants were not equally distributed $\left(\chi^{2}=\right.$ 279.64; $\mathrm{P}<0.0001)$. Genus Iotonchus and Dorylaimus were found in all plants and genus Discolaimus was found only in 30 Kiwi plants (Figure 1). Among the identified nematodes ca. 40 Kiwi plants were infected by predatory nematodes (Mononchus Spp., Parahadronchus Spp., Iotonchus Spp., Discolaimus Spp. and Dorylaimus Spp.), 40.96\% by bacterivorous nematodes (Rhabditis Spp., Mesorhabditis Spp., Cephalobus Spp. and Eucephalobus Spp.) and 9.64\% by herbivorous nematode (Helicotylenchus Spp.) (Figure 2).

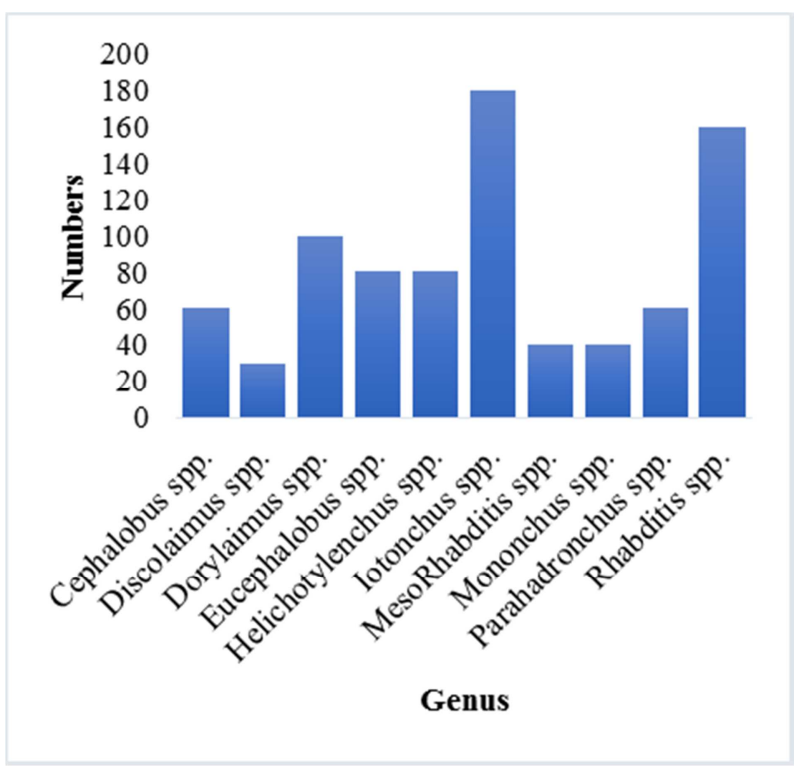

Figure 1. Prevalence of nematodes in $\mathrm{CHC}$.

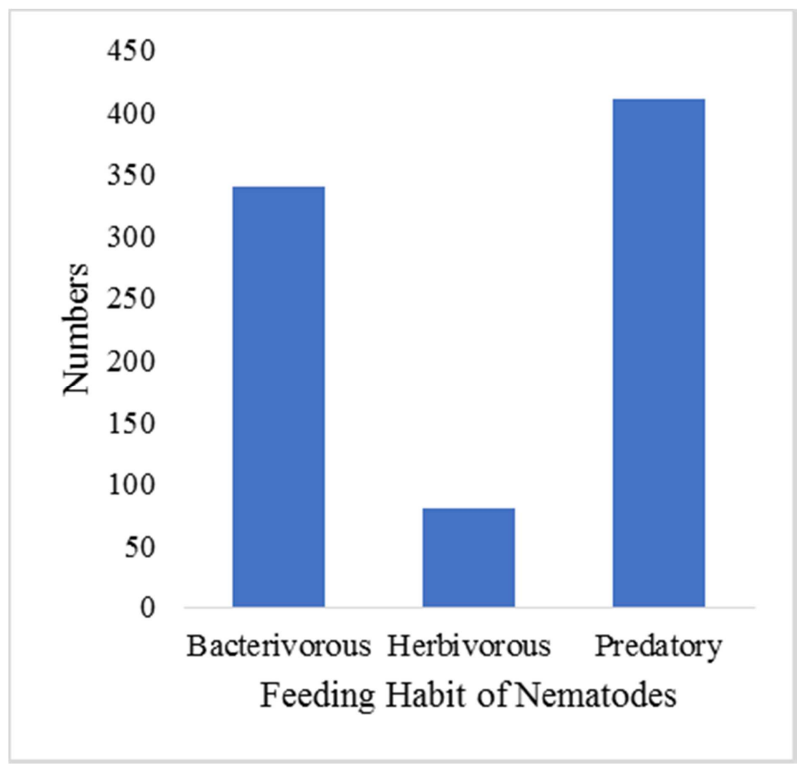

Figure 2. Community composition of soil nematodes.

Among the identified nematodes in the Kiwi plants the free-living species such as Iotonchus Spp. Rhabditis Spp., Dorylaimus Spp., Eucephalobus Spp., Parahdronchus Spp., Cephalobus Spp., Mononchus Spp., Mesorhabditis Spp. and Discolaimus Spp. were dominant, probably due 
to the regular supplying of organic matters to the Kiwi plants. This assumption can be supported by the occurrence of free-living nematodes Iotonchus Spp. and Rhabditis Spp. in established grasslands [23, 24]. The occurrence of predatory nematodes (Mononchus Spp., Parahadronchus Spp., Iotonchus Spp., Discolaimus Spp. and Dorylaimus Spp.), probably supported by the occurrence of numerous free-living nematodes.

The identified herbivorous nematode (Helicotylenchus Spp.) in the Kiwi plants was less dominant, probably due to the presence of free-living nematodes like Iotonchus Spp. Rhabditis Spp., Dorylaimus Spp., Eucephalobus Spp., Parahdronchus Spp., Cephalobus Spp., Mononchus Spp., Mesorhabditis Spp. and Discolaimus Spp. which graze on bacteria, fungi and other phyto-parasitic nematodes, thus they control the populations of harmful micro-organisms [25]. Generally, plant parasitic nematodes can be found in less number in those plants where fungivorous Eucephalobus Spp. are common are more common in homogeneous crop residues such as in maize (Zea mays) [26].

The predatory nematodes such as Mononchus Spp., Parahadronchus Spp., Iotonchus Spp., Discolaimus Spp. and Dorylaimus Spp. were highest in Kiwi plants of this study area which might be due to the high number of bacterivorous nematodes (Rhabditis spp., Mesorhabditis spp., Cephalobus spp. and Eucephalobus spp.). These genera are supposed to be common food of these predatory nematodes. Increase of predatory nematodes cause declines in prey populations, which in turn prevents further increase of the predator population [27]. Out of all identified nematodes from rhizosphere of Kiwi plants, the bacterivorous nematodes like Rhabditis spp., Mesorhabditis spp., Cephalobus spp. and Eucephalobus spp. were dominant, probably due to the regular supplying of organic matters to the Kiwi plants. Nematode occurrences can be supported by litter present in the soil [28].

\section{Conclusions}

The presence of predatory nematodes and bacterivore nematodes almost equal in number and also high number of herbivorous nematode species in CHC study area may be due to the use of Compost manure, Nitrogen, Phosphorus, Murat of Potash and Bone meal as fertilizer in the rhizosphere soil of Kiwi plants. Therefore, we recommend regular use of manures and Kiwi plants treatment.

\section{Acknowledgements}

Authors thank Dr. Arvind Kumar Keshari and late Ashok Bahadur Bam for their kind cooperation for species identification. We also thank Central Departments of Zoology and Environmental Science for providing lab for this research. Furthermore, we thank Central Horticulture Centre, Kirtipur, Kathmandu, Nepal for research permission.

\section{References}

[1] Ayala, F. J., Rzhetsky, A. and Ayala, F. J. Origin of the metazoan phyla: Molecular clocks confirm paleontological estimates. Proceeding of the National Academy of Science of the United States of America, 1998; 95: 606-611.

[2] Sanderson, M. J. Molecular data from 27 proteins do not support a Precambrian origin of land plants. American Journal of Botany, 2003; 90: 954-56.

[3] Blaxter, M. L., De Ley, P., Garey, J. R., Liu, L. X., Scheideman, P., Vierstraete, A., Vanfleteren, J. R., Mackey, L. Y., Dorris, M., Frisse, L. M., Vida, J. T. and Thomas, W.K. A molecular evolutionary framework for the phylum Nematoda. Nature, 1998; 392: 71-75.

[4] Blaxter, M. M., Dorris, M. and De Ley, P. Patterns and processes in the evolution of animal parasitic nematodes. Nematologica, 2000; 2: 43-55.

[5] Singha, S., Singh, B. and Singh, A. P. Nematodes: A Threat to Sustainability of Agriculture. Proceeding of the Environment Science, 2015; 29: 215 - 216.

[6] Nicol, L., Turner, S. J., Coyne, D. L. and Nijs, N. D. Current nematode threats to agriculture, 2011; 10.1007/978-94-0070434-3_2.

[7] Curl, E. A. Control of plant disease by crop rotation. The Botanical Review, 1963; 29: 413-479.

[8] Nusbaum, C. J., and Ferris, H. The role of cropping systems in nematode population management. Annual Review of Phytopathology, 1973; 11: 423-440.

[9] Freckman, D. W. Nematodes in Soil Ecosystems. University of Texas Press, Austin, TX., 1982.

[10] Ingham, R. E. and Detling, J. K. Plant-herbivore interactions in a North American mixed-grass prairie. III. Soil nematode populations and root biomass on Cynomys ludovicianus colonies and adjacent uncolonized areas. Oecologia, 1984; 63: 307-313.

[11] Yeates, G. W., Bongers, T., de Goede, R. G. M., Freckman, D. W. and Georgieva, S. S. Feeding habits in soil nematode families and genera- an outline for soil ecologists. Journal of Nematology, 1993; 25: 315-331.

[12] Wilson, E. H., Yichang, A. R. and Ferguson. E. H. Wilson, Yichang and the Kiwifruit. http: //arnoldia.arboretum.harvard.edu/pdf/articles/115 5.pdf. 15 April, 2017.

[13] Beutel, J. A. Kiwifruit production in California. Division of Agriculture and Natural Resources, 1990.

[14] Watson, R. N., Wilson, E. A. and Marsden, R. S. Distribution of plant- parasitic nematodes in the rhizosphere of Kiwi fruit. Acta Hortic., 1992; 297, 537-544; doi: 10.17660/ ActaHortic.1992.2 97. 70.

[15] CHC. Central Horticulture Centre. Annual Report published by Central Horticulture Centre, Kirtipur, Kathmandu, 20112012.

[16] Thapa, D. B. Kiwifruit culture. Lumbini Printing and Publication Pvt. Ltd., Ghattekulo, Kathmandu, Nepal, 2012; 23. 
[17] Cobb, N. A. Estimating the nema population of soil. U. S. Dep. Agric. Tech. Circ. 1: 48. Coetzee, V. 1967. Species of the Genus Iotonchus (Nematoda: Mononchidae) Occurring in Southern Africa. Nematologica, 1918; 13 (3): 367-377.

[18] Baermann, G. Eineeinsache method zurauffindung von ankylostomum (Nematoden) larven in erdproben. Genee Sk. Tijdschr. Nederlands-Indië, 1917; 57: 131-137.

[19] Seinhorst, J. W. Killing of nematodes for taxonomic study with hot F.A. 4:1. Nematologica, 1966; 12: 178.

[20] Seinhorst, J. W. A rapid method for the transfer of nematodes from fixative to anhydrous glycerin. Nematologica, 1959; 4: 67-69.

[21] Smart, G. C. and Nguyen, K. B. Illustrated key for the identification of common nematodes in Florida. University of Florida Gainesville, Florida, 1988.

[22] R Core Team. R: A language and environment for statistical computing. R Foundation for Statistical Computing, Vienna, Austria. URL https: //www.R-project.org/, 2017.

[23] Reyes, P. S. and Domingo, J. Mononchid nematodes from Spain. Description of Iotonchus rotundicaudatus sp. $\mathrm{n}$. and observations on I. zschokkei (Menzel, 1913) Altherr, 1955. Review on Nematology, 1991; 14 (3): 353-360.
[24] Čerevková, A. Diversity and Distribution of Nematode Communities in Grassland in Relation to Its Establishment Age and Utilization. Nova Science Publishers, Inc., 2011, 115 .

[25] FAO. Food and Agriculture Organization of the United Nations. The importance of soil organic matter. Viale delle Terme di Caracalla, 00100 Rome, Italy, 2005, 64.

[26] McSorley, R. and Frederick, J. J. Nematode Population Fluctuations during Decomposition of Specific Organic Amendments. Journal of Nematology, 1999; 31 (1): 37-44.

[27] Djigal, D., Brauman, A., Diop, T., Chotte, J. L. and Villenave, C. Influence of bacterial-feeding nematodes (Cephalobidae) on soil microbial communities during maize growth. Soil Biology and Biochemistry, 2004; 36: 323-331.

[28] Xue, Q. Nematode diversity of soil and litter in Mount Hamiguitan, the Philippines, with morphological and phylogenetic analysis of selected species. M. Sc. Thesis. Department of Biology, Ghent University, Ghent, B-9000, Belgium, 2013. 